\title{
PENGARUH SISTEM PENGENDALIAN INTERN, PRINSIP PENGELOLAAN KEUANGAN DAERAH, DAN PENERAPAN STANDAR AKUNTANSI PEMERINTAHAN, TERHADAP KUALITAS LAPORAN KEUANGAN DAERAH PADA ORGANISASI PERANGKAT DAERAH KABUPATEN JEPARA
}

\author{
${ }^{1}$ Chelwa Ulya Fatmala, ${ }^{2}$ Naila Rizki Salisa \\ Program Studi Akuntansi, Fakultas Ekonomi dan Bisnis, Universitas Muria Kudus \\ Ichelwa.ulya@yahoo.com \\ ${ }^{2}$ naila.rizki@umk.ac.id
}

\begin{abstract}
ABSTRAK
Penelitian ini bertujuan untuk mengetahui pengaruh sistem pengendalian intern, prinsip pengelolaan keuangan daerah, dan penerapan standar akuntansi pemerintahan terhadap kualitas laporan keuangan daerah. Metode analisis data yang digunakan adalah uji validitas, uji reabilitas, uji asumsi klasik yang terdiri dari uji normalitas, uji multikolinearitas, uji heteroskedastisitas, dan uji hipotesisnya menggunakan analisis regresi linear berganda, uji koefisien determinasi, uji statistik F, dan uji statistik t. Metode analisis yang digunakan dalam penelitian ini adalah analisis regresi linear berganda dengan menggunakan program SPSS 23. Hasil penelitian menunjukkan bahwa sistem pengendalian intern dan prinsip pengelolaan keuangan daerah secara parsial berpengaruh signifikan terhadap kualitas laporan keuangan daerah pada OPD Kabupaten Jepara, sedangkan penerapan standar akuntansi pemerintahan secara parsial tidak berpengaruh signifikan terhadap kualitas laporan keuangan daerah pada OPD Kabuapten Jepara, dan secara simultan sistem pengendalian intern, prinsip pengelolaan keuangan daerah, dan penerapan standar akuntansi pemerintahan berpengaruh terhadap kualitas laporan keuangan daerah pada OPD Kabupaten Jepara. Koefisien determinasi dari sistem pengendalian intern, prinsip pengelolaan keuangan daerah, dan penerapan standar akuntansi memberikan sebesar 56,4\% kepada variabel kualitas laporan keuangan daerah, 43,6\% dipengaruhi oleh variabel lain.
\end{abstract}

Kata kunci: sistem pengendalian intern, prinsip pengelolaan keuangan daerah, penerapan standar akuntansi pemerintahan, kualitas laporan keuangan daerah

\begin{abstract}
This study aimed at finding out the effect of internal control system, the principle of regional financial management, and application of government accounting standards to the quality of local financial statements. The analysis was conducted by using validity test, reliability test, classical assumption test consisting of normality test, multicolinearity test, heteroscedasticity test, and hypothesis test using multiple linear regression analysis, coefficient of determination test, statistic test $F$, and statistical test $t$. The method of analysis used in this study is multiple linear regression analysis using SPSS 23. The results showed that the internal control system and the principle of regional financial management significant partially effect on the quality of local financial statements on OPD of Jepara Regency, while the application of accounting standards government partially no significant effect on the quality of local financial statements on OPD of Jepara Regency, and simultaneously the internal control system, the principle of regional financial management, and the application of government accounting standards affect the quality of local financial statements on OPD of Jepara Regency. The coefficient of determination of the internal control system, the principle of regional financial management, and the application of government accounting standards gives $56.4 \%$ to the variable quality of local financial statements, $43.6 \%$ influenced by other variables.
\end{abstract}

Keywords : internal control system, principles of regional financial management, government accounting standards, quality of local financial statements 


\section{P ISSN \\ [ACCOUNTING GLOBAL JOURNAL] E ISSN}

\section{PENDAHULUAN}

Pemberlakukan otonomi daerah merupakan salah satu langkah dalam mewujudkan desentralisasi pemerintahan yang sesungguhnya, dengan maksud untuk mempercepat mewujudkan kesejahteraan masyarakat melalui peningkatan pelayanan, pemberdayaan, dan peran serta masyarakat. Dengan adanya pemberlakuan otonomi daerah oleh pemerintah pusat, maka pemerintah daerah mempunya tanggungjawab yang lebih besar untuk mendayagunakan potensi daerahnya masing-masing demi memajukan daerah tersebut (Dewi, dkk (2014)), dalam hal ini pemerintah daerah Kabupaten Jepata. Dengan otonomi, Kabupaten Jepara dituntut untuk mencari alternatif sumber pembiayaan pembangunan tanpa mengurangi harapan masih adanya bantuan dan bagian (sharing) dari pemerintah pusat dan menggunakan dana publik sesuai dengan prioritas dan aspirasi masyarakat (Dewi, dkk (2014)). Pada Pemerintah Kabupaten Jepara, pelaksanaan pengelolaan keuangan daerah dan pendanaan diatur dalam Peraturan Daerah No. 7 Tahun 2012 tentang Pertanggungjawaban Pelaksanaan Anggaran Pendapatan dan Belanja Daerah, Peraturan Daerah No. 10 Tahun 2012 tentang Perubahan Anggaran Pendapatan dan Belanja Daerah, dan Peraturan Daerah Kabupaten Jepara No. 11 Tahun 2013 tentang Pokok-Pokok Pengelolaan Keuangan Daerah.

Laporan keuangan dalam pemerintah daerah berperan dalam menciptakan akuntabilitas pemerintah daerah. Semakin besar tuntutan terhadap pelaksanaan akuntabilitas pemerintah daerah memperbesar kebutuhan akan transparansi informasi keuangan pemerintah daerah (Nordiawan dan Hertianti, 2010: 125). Laporan keuangan disusun untuk memberikan informasi tentang posisi harta, hutang, dan ekuitas yang terjadi dalam rumah tangga perusahaan serta laba dan ruginya. Tujuan umum laporan keuangan adalah menyajikan informasi mengenai posisi keuangan, realisasi anggaran, arus kas, dan kinerja keuangan suatu entitas pelaporan yang bermanfaat bagi para pengguna. Suatu ukuran-ukuran normatif yang perlu diwujudkan dalam informasi akuntansi untuk memenuhi tujuannya yaitu karakteristik kualitas laporan keuangan. Terdapat empat karakteristik kualitas laporan keuangan yaitu relevan, andal, dapat dibandingkan, dan dapat dipahami (Mursyidi, 2009:47).

Menurut Mursyidi (2009:19), dalam hasil pemeriksaan keuangan oleh BPK akan menghasilkan opini yang merupakan pernyataan profesional pemeriksa mengenai kewajaran informasi keuangan yang disajikan. Di dalam penilaian laporan keuangan yang 
baik terdapat empat hal penilaian, yaitu Wajar Tanpa Pengecualian (WTP), wajar dengan pengecualian, tidak wajar, dan menolak memberikan opini.

Hasil opini Laporan Keuangan Pemerintah Daerah (LKPD) yang diberikan Badan Pemeriksa Keuangn (BPK) kepada Pemerintah Daerah Kabupaten Jepara pada tahun 2010 sampai tahun 2016 opini tidak megalami perubahan yaitu beropini Wajar Tanpa Pengecualian (WTP), sehingga dengan adanya hal ini dapat diindikasi bahwa kualitas laporan keuangan Pemerintah Kabupaten Jepara sangatlah baik dan efektif. Opini tersebut dapat menggambarkan bahwa sistem pengendalian intern, prinsip pengelolaan keuanga, dan penerapan SAP dinilai telah memadai. Akan tetapi, walaupun telah meraih opini WTP, kinerja pemerintah daerah Kabupaten Jepara ada beberapa yang dinilai belum sepenuhnya baik, untuk tetap mempertahankan opini WTP maka Kabupaten Jepara harus memperhatikan faktor-faktor yang dapat mempengaruhi kualitas laporan keuangan. Beberapa yang dapat diperhatikan untuk tetap mempertahankan opini tersebut yaitu sistem pengendalian intern, prinsip pengelolaan keuangan daerah, dan standar akuntansi pemerintahan dapat diterapkan sesuai dengan perundang-udangan yang ada.

Penelitian ini replikasi dari penelitian yang dilakukan oleh Moha, dkk (2017) dimana menunjukkan bahwa terdapat pengaruh sistem pengendalian intern dan prinsip pengelolaan keuangan daerah terhadap kualitas laporan keuangan daerah Kabupaten Bolaang Mongondow Selatan. Penelitian Moha dkk (2017) menjadi faktor pendorong bagi peneliti untuk melakukan penelitian yang relative sejenis.

\section{Perbedaan Penelitian}

Penelitian ini berbeda dengan penelitian yang dilakukan sebelumnya. Pertama menambah variabel independen penerapan SAP. Kedua yaitu perbedaan objek dari penelitian terdahulu yaitu Pemerintah Daerah Kabupaten Bolaang Mongondow Selatan, sedangkan objek penelitian ini adalah organisasi perangkat daerah Kabupaten Jepara.

\section{TINJAUAN PUSTAKA}

\section{Teori Keagenan}

Teori keagenan pada dasarnya merupakan teori yang muncul karena adanya konflik kepentingan antara prinsipal dan agen. jika diimplementasikan pada hubungan antara masyarakat dan pemerintah adalah seperti hubungan antara prinsipal dan agen. Masyarakat adalah prinsipal dan pemerintah adalah agen. Prinsipal memberika kewenangan dan sumber daya kepada agen, sebagai bentuk pertanggung jawaban agen memberikan laporan 
pertanggungjawaban terhadap prinsipal (Gilardi, 2001). Dalam pelaporan keuangan, pemerintah yang bertindak sebagai agen mempunyai kewajiban menyajikan informasi yang bermanfaat bagi para pengguna informasi keuangan pemerintah yang bertindak sebagai prinsipal dalam menilai akuntabilitas dan membuat keputusan baik keputusan ekonomi, sosial, maupun politik

\section{Teori Atribusi}

Teori atribusi mempelajari proses bagaimana seseorang menginterpretasikan suatu peristiwa, alasan, atau sebab perilakunya. Kemampuan untuk mendeteksi kecurangan laporan keuangan juga memiliki kaitan dengan teori atribusi. Menurut teori atribusi, tingkat kinerja yang diharapkan dimasa depan dalam tugas tertentu tergantung pada penyebab khusus keberhasilan atau kegagalan sebelumnya dalam tugas yang sama (Kelley 1972-1973).

\section{Teori Kepatuhan}

Teori kepatuhan merupakan teori dalam ilmu sosial terutama psikologis dan sosiologi yang lebih menekankan pada pentingnya proses sosialisasi dalam mempengaruhi perilaku kepatuhan seorang individu. Menurut Tyler (Susilowati, 1998) terdapat dua perspektif yaitu instrumental dan normatif. Pada bidang akuntansi perspektif yang diterapkan adalah perspektif normatif karena berhubungan dengan apa yang orang anggap sebagai moral dan berlawanan dengan kepentingan pribadi mereka. Apabila kepatuhan entitas pelaporan dalam menyampaikan laporan pertanggung jawaban berupa laporan keuangan merupakan suatu hal yang mutlak dalam memenuhi kepatuhan terhadap pengungkapan informasi dalam laporan keuangan yang sesuai dengan Standar Akuntansi Pemerintah.

\section{Kerangka Pemikiran}

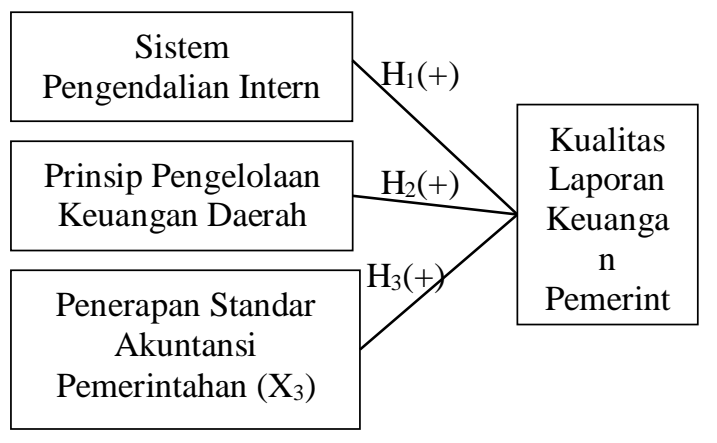

Sumber : Moha dkk (2017) dan Wati (2014) yang telah dimodifikasi untuk penelitian ini 


\section{Perumusan Hipotesis}

\section{Pengaruh Sistem Pengendalian Intern terhadap Kualitas Laporan Keuangan Daerah}

Pengendalian intern adalah suatu proses yang dipengaruhi oleh dewan komisaris, manajemen, dan personil suatu usaha lainnya, yang dirancang untuk mendapatkan keyakinan memadai tentang pencapaian tujuan dalam hal-hal berikut; keandalan laporan keuangan, kesesuaian dengan undang-undang, efektifitas dan efisiensi operasi, dan peraturan yang berlaku. Semakin efektif penerapan sistem pengendalian intern maka kualitas laporan keuangan pemerintah daerah juga akan semakin berkualitas. Laporan keuangan yang akan dihasilkan dapat memenuhi karakteristik relevan, andal, dapat dibandingkan, dan dapat dipahami.

\section{$H_{1}$ : Sistem Pengendalian Intern berpengaruh positif trhadap Kualitas Laporan Keuangan Daerah}

Pengaruh Prinsip Pengelolaan Keuangan Daerah terhadap Kualitas Laporan

\section{Keuangan Daerah}

Pengelolaan keuangan daerah adalah keseluruhan kegiatan yang meliputi perencanaan, pelaksanaan, penatausahaan, pelaporan, pertanggung jawaban, dan pengawasan keuangan daerah (PP No. 58 Tahun 2005, pasal 1). Pengelolaan keuangan daerah dilaksanakan dengan pendekatan kinerja yang berorientasi pada prinsip-prinsip pengelolaan keuangan daerah yang diperlukan untuk mengontrol kebijakan keuangan daerah, yaitu; akuntabilitas, value for money, kejujuran dalam mengelola keuangan publik, transparansi, dan pengendalian. Dengan prinsip pengelolaan keuangan daerah yang efektif maka dapat menghasilkan laporan keuangan yang berkualitas.

\section{$\mathbf{H}_{2}$ : Prinsip Pengelolaan Keuangan Daerah berpengaruh positif terhadap Kualitas} Laporan Keuangan Daerah

\section{Pengaruh Penerapan Standar Akuntansi Pemerintahan terhadap Kualitas Laporan}

\section{Keuangan Daerah}

Menurut PP No. 71 Tahun 2010 tentang Standar Akuntansi Pemerintahan (Pasal 1), standar akuntansi pemerintahan adalah prinsip-prinsip akuntansi yang ditetapkan dalam menyusun dan menyajikan laporan keuangan pemerintah. Penerapan standar akuntansi pemerintahan menjamin bahwa laporan keuangan disusun sesuai ketentuan yang berlaku, 


\section{P ISSN \\ [ACCOUNTING GLOBAL JOURNAL] \\ E ISSN}

sehingga dengan penerapan standar akuntansi pemerintahan yang sesuai dengan perundang-undangan maka dapat menghasilkan laporan keuangan yang berkualitas.

\section{$\mathrm{H}_{3}$ : Penerapan Standar Akuntansi Pemerintahan berpengaruh posistif terhadap Kulitas Laporan Keuangan Daerah}

\section{METODE PENELITIAN}

\section{Populasi, Sampel, dan Teknik Pengambilan Sampel}

Populasi dalam penelitian ini adalah seluruh organisasi perangkat daerah di Kabupaten Jepara yang berjumlah 43. Teknik pengambilan sampel yang digunakan dalam penelitian ini dengan menggunakan metode purposive sampling. Penentuan sampel dengan kriteriakriteria yang ditentukan untuk sampel. Sampel dalam penelitian ini berjumlah 79 responden, yang sudah sesuai dengan kriteria-kriteria sampel.

\section{Metode Analisis Data}

Penelitian ini menggunakan uji validitas, uji reliabilitas, uji asumsi klasik yang terdiri dari uji normalitas, uji multikolonieritas, uji heteroskedastisitas dan uji hipotesisnya menggunakan uji koefisien determinasi $\left(\mathrm{R}^{2}\right)$, uji statistik $\mathrm{F}$ dan uji statistik t. Metode analisis yang digunakan dalam penelitian ini adalah analisis regresi linear berganda dengan menggunakan SPSS 23.

\section{HASIL DAN PEMBAHASAN}

\section{Gambaran Umum Objek Penelitian}

Populasi penelitian ini adalah seluruh Organisasi Perangkat Daerah (OPD) di Kabupaten Jepara. Metode pengambilan sampel menggunakan metode purposive sampling. Pengumpulan data dilakukan dengan penyebaran kuesoiner penelitian secara langsung kepada karyawan yang bekerja pada OPD di Kabupaten Jepara. Kuesioner yang disebarkan berjumlah 79 buah dan jumlah kuesioner yang kembali adalah sebanyak 74 kuesioner. Setelah dilakukan pengecekkan, tinggal 71 kuesioner yang dapat diolah. 


\section{Ststistik Deskriptif}

Tabel 4.1

Descriptive Statistics

\begin{tabular}{|l|r|r|r|r|c|}
\hline & & Min & Max & Mean & $\begin{array}{c}\text { Std. } \\
\text { Deviatio } \\
\mathrm{n}\end{array}$ \\
\hline $\begin{array}{l}\text { Kualitas } \\
\text { Laporan } \\
\text { Keuangan } \\
\text { Daerah }\end{array}$ & 71 & 17 & 25 & 21.8451 & 2.15571 \\
$\begin{array}{l}\text { SPI } \\
\text { Prinsip } \\
\text { Pengelolaan } \\
\begin{array}{l}\text { Keuangan } \\
\text { Daerah } \\
\text { Penerapan } \\
\text { SAP }\end{array}\end{array}$ & 71 & 19 & 25 & 21.5070 & 1.85837 \\
$\begin{array}{l}\text { Valid N } \\
\text { (listwise) }\end{array}$ & 71 & 17 & 25 & 20.7887 & 1.98505 \\
\hline
\end{tabular}

Sumber : Output SPSS 23, 2018

\section{Uji Validitas}

Tabel 4.2

\section{Hasil Uji Validitas}

\begin{tabular}{|l|c|c|c|c|}
\hline Variabel & $\begin{array}{c}\text { No. } \\
\text { Item }\end{array}$ & $\begin{array}{c}\mathbf{r} \\
\text { Hitung }\end{array}$ & $\begin{array}{c}\mathbf{r} \\
\text { Tabel }\end{array}$ & Ket. \\
\hline $\begin{array}{l}\text { Kualitas } \\
\text { Laporan }\end{array}$ & 1. & 0,803 & 0,2335 & Valid \\
\cline { 2 - 5 } $\begin{array}{l}\text { Keuangan } \\
\text { Daerah (Y) }\end{array}$ & 2. & 0,842 & 0,2335 & Valid \\
\cline { 2 - 5 } & 3. & 0,707 & 0,2335 & Valid \\
\cline { 2 - 5 } & 4. & 0.770 & 0,2335 & Valid \\
\cline { 2 - 5 } & 5. & 0,794 & 0,2335 & Valid \\
\hline \multirow{2}{*}{$\begin{array}{l}\text { Sistem } \\
\text { Pengendali } \\
\text { an Intern } \\
\left(\mathrm{X}_{1}\right)\end{array}$} & 1. & 0,682 & 0,2335 & Valid \\
\cline { 2 - 5 } & 2. & 0,708 & 0,2335 & Valid \\
\cline { 2 - 5 } & 3. & 0,687 & 0,2335 & Valid \\
\cline { 2 - 5 } & 4. & 0.662 & 0,2335 & Valid \\
\cline { 2 - 5 } & 5. & 0,693 & 0,2335 & Valid \\
\hline Prinsip & 1. & 0,662 & 0,2335 & Valid \\
\hline
\end{tabular}




\begin{tabular}{|l|c|c|c|c|}
\hline Pengelolaa & 2. & 0,619 & 0,2335 & Valid \\
\cline { 2 - 5 } $\begin{array}{l}\text { Keuangan } \\
\text { Daerah } \\
\left(\mathrm{X}_{2}\right)\end{array}$ & 3. & 0,548 & 0,2335 & Valid \\
\cline { 2 - 5 } & 4. & 0,464 & 0,2335 & Valid \\
\cline { 2 - 5 } & 5. & 0,649 & 0,2335 & Valid \\
\cline { 2 - 5 } & 6. & 0,675 & 0,2335 & Valid \\
\cline { 2 - 5 } & 7. & 0,762 & 0,2335 & Valid \\
\cline { 2 - 5 } & 8. & 0,630 & 0,2335 & Valid \\
\cline { 2 - 5 } & 9. & 0,308 & 0,2335 & Valid \\
\cline { 2 - 5 } & 10. & 0,586 & 0,2335 & Valid \\
\hline $\begin{array}{l}\text { Penerapan } \\
\text { Standar } \\
\text { Akuntansi }\end{array}$ & 1. & 0,779 & 0,2335 & Valid \\
\cline { 2 - 5 } $\begin{array}{l}\text { Pemerintah } \\
\text { an (X) }\end{array}$ & 2. & 0,767 & 0,2335 & Valid \\
\cline { 2 - 5 } & 3. & 0,718 & 0,2335 & Valid \\
\cline { 2 - 5 } & 4. & 0,762 & 0,2335 & Valid \\
\cline { 2 - 5 } & 5. & 0,642 & 0,2335 & Valid \\
\hline
\end{tabular}

Sumber : Output SPSS 23, 2018

Berdasarkan tabel diatas dapat diketahui $r$ hitung dari semua variabel (SPI, Prinsip pengelolaan keuangan daerah, Penerapan SAP, dan Kualitas laporan keuangan daerah) dalam semua item pertanyaan adalah valid karena $r$ hitung $>r$ tabel $(0,2335)$.

\section{Uji Reabilitas}

Tabel 4.3

Hasil Uji Reabilitas

\begin{tabular}{|l|c|c|}
\hline \multicolumn{1}{|c|}{ Kuesioner } & $\begin{array}{c}\text { Alpha } \\
\text { Cronbach }\end{array}$ & Ket. \\
\hline $\begin{array}{l}\text { Kualitas Laporan } \\
\text { Keuangan Daerah }\end{array}$ & 0,842 & Reliabel \\
\hline $\begin{array}{l}\text { Sistem Pengendalian } \\
\text { Intern }\end{array}$ & 0,715 & Reliabel \\
\hline $\begin{array}{l}\text { Prinsip Pengelolaan } \\
\text { Keuangan Daerah }\end{array}$ & 0,746 & Reliabel \\
\hline $\begin{array}{l}\text { Penerapan Sistem } \\
\text { Akuntansi }\end{array}$ & 0,785 & Reliabel \\
\hline
\end{tabular}


\begin{tabular}{|l|l|l|}
\hline Pemerintahan & & \\
\hline
\end{tabular}

Sumber : Output SPSS 23, 2018

Berdasarkan tabel 4.3 hasil uji reabilitas diatas, variabel-variabel yang digunakan dalam penelitian ini menunjukkan Alphan Cronback $>$ 0,70. Sehingga dapat disimpulkan bahwa pertanyaan dalam setiap variabel dapat dikatakan konsisten dari instrument penelitian.

\section{Uji Normalitas}

Tabel 4.4

One-Sample Kolmogorov-Smirnov Test

\begin{tabular}{|ll|r|}
\hline & & $\begin{array}{c}\text { Unstandardized } \\
\text { Residual }\end{array}$ \\
\hline $\mathrm{N}$ & Mean & 71 \\
Normal & Std. & .0000000 \\
Parameters & Deviation & .06336604 \\
& Absolute & .104 \\
Most Extreme & .092 \\
Differences & Positive & -.104 \\
& Negative & .104 \\
Test Statistic & & .056 \\
Asymp. Sig. (2-tailed) &
\end{tabular}

Sumber : Output SPSS 23, 2018

Dari tabel 4.4 diatas diketahui bahwa nilai probabilitas $0,061>0,050$ maka data berdistribusi normal. Berdasarkan uji normalitas diatas menunjukkan bahwa metode uji statistik non parametrik Kolomogrov - Smirnov (K-S) memenuhi asumsi normalitas.

\section{Uji Multikolinearitas}

Tabel 4.5

Hasil Uji Multikolinearitas

\begin{tabular}{|l|r|c|}
\hline \multirow{2}{*}{ Model } & \multicolumn{2}{|c|}{ Collinearity Statistics } \\
\cline { 2 - 3 } & Tolerance & \multicolumn{1}{c|}{ VIF } \\
\hline $\begin{array}{l}\text { Sistem Pengendalian } \\
\text { Intern }\end{array}$ & .472 & 2.117 \\
$\begin{array}{l}\text { Prinsip Pengelolaan } \\
\text { Keuangan Daerah }\end{array}$ & .517 & 1.936 \\
$\begin{array}{l}\text { Penerapan Standar } \\
\text { Akuntansi } \\
\text { Pemerintahan } \\
\text { Sistem Akuntansi } \\
\text { Keuangan Daerah }\end{array}$ & .378 & 2.642 \\
\hline
\end{tabular}

Sumber : Output SPSS 23, 2018 


\section{[ACCOUNTING GLOBAL JOURNAL] E ISSN}

Tabel 4.5 persamaan diatas menunjukkan bahwa nilai tolerance lebih dari 0,1 dan nilai VIF kurang dari 10, sehingga dapat disimpulkan tidak terjadi multikolinearitas antar variabel independen.

\section{Uji Heteroskedastisitas}

Tabel 4.6

\section{Hasil Uji Heteroskedastisitas}

\begin{tabular}{|c|c|c|c|c|c|c|}
\hline & \multirow{2}{*}{ Model } & \multicolumn{2}{|c|}{ Unstandardized Coefficients } & \multirow{2}{*}{$\begin{array}{l}\text { Standardized } \\
\text { Coefficients } \\
\text { Beta }\end{array}$} & \multirow[t]{2}{*}{$\mathrm{t}$} & \multirow[t]{2}{*}{ Sig. } \\
\hline & & B & Std. Error & & & \\
\hline \multirow[t]{4}{*}{1} & (Constant) & .012 & .208 & & .059 & .953 \\
\hline & $\begin{array}{l}\text { Sistem } \\
\text { Pengendalia } \\
\text { Intern }\end{array}$ & .014 & .084 & .030 & .169 & .866 \\
\hline & $\begin{array}{l}\text { Prinsip } \\
\text { Pengelolaan } \\
\text { Keuangan } \\
\text { Daerah }\end{array}$ & .028 & .072 & .066 & .392 & .696 \\
\hline & $\begin{array}{l}\text { Penerapan } \\
\text { Standar } \\
\text { Akuntansi } \\
\text { Pemerintahan }\end{array}$ & -.037 & .085 & -.085 & -.430 & .669 \\
\hline
\end{tabular}

Sumber : Output SPSS 23, 2018

Tabel 4.6 diatas menunjukkan bahwa diketahui bahwa tidak ada nilai sig. kurang dari 0,05, sehingga dapat disimpulkan bahwa terjadi homoskedastisitas.

\section{Uji Statistik F}

Tabel 4.7

Hasil Perhitungan Uji Statistik F

\begin{tabular}{|l|r|r|r|r|r|}
\hline Model & $\begin{array}{c}\text { Sum } \\
\text { of } \\
\text { Square } \\
\text { s }\end{array}$ & df & $\begin{array}{c}\text { Mean } \\
\text { Squar } \\
\mathrm{e}\end{array}$ & F & Sig. \\
\hline $\begin{array}{l}\text { Regres } \\
\text { sion }\end{array}$ & .393 & 3 & .131 & 31.221 & $.000^{\mathrm{b}}$ \\
$\begin{array}{l}\text { Residu } \\
\text { al } \\
\text { Total }\end{array}$ & .281 & 67 & .004 & & \\
\hline
\end{tabular}

Sumber : Output SPSS 23, 2018 
Berdasarkan tabel 4.7 nilai $F$ diperoleh 31,221 dengan tingkat signifikasi 0,000. Tingkat signifikasi lebih kecil dari 0,05 maka ini berarti sistem pengendalian intern, prinsip pengelolaan keuangan daerah, dan penerapan standar akuntansi pemerintahan, secara simultan berpengaruh terhadap kualitas laporan keuagan daerah.

\section{Analisis Regresi Linear Berganda}

Tabel 4.8

Hasil Pengujian Regresi Linear Berganda

\begin{tabular}{|c|c|c|c|c|c|}
\hline \multirow[t]{2}{*}{ Model } & \multicolumn{2}{|c|}{$\begin{array}{l}\text { Unstandardized } \\
\text { Coefficients }\end{array}$} & $\begin{array}{l}\text { Stand } \\
\text { ardize } \\
\quad \mathrm{d} \\
\text { Coeffi }\end{array}$ & \multirow[t]{2}{*}{$\mathrm{t}$} & \multirow[t]{2}{*}{ Sig. } \\
\hline & B & $\begin{array}{l}\text { Std. } \\
\text { Error }\end{array}$ & Beta & & \\
\hline (Constant) & -.097 & .330 & & -.293 & .770 \\
\hline SPI & .467 & .133 & .402 & 3.506 & .001 \\
\hline $\begin{array}{l}\text { Prnsip } \\
\text { Pengelolaa } \\
\mathrm{n} \\
\text { Keuangan } \\
\text { Daerah }\end{array}$ & .428 & .115 & .409 & 3.724 & .000 \\
\hline $\begin{array}{l}\text { Penerapan } \\
\text { SAP }\end{array}$ & 056 & .135 & .053 & .417 & .678 \\
\hline
\end{tabular}

Sumber : Output SPSS 23, 2018

\section{Pembahasan}

\section{Pengaruh Sistem Pengendalian Intern terhadap Kualitas Laporan Keuangan Daerah}

Berdasarkan tabel 4.8 diketahui nilai koefisien regresi dari variabel sistem pengendalian intern sebesar 0,467 mempunyai t hitung sebesar 3,506 dengan probabilitas (sig.) 0,001 yang lebih kecil dari nilai $\alpha(0,001<0,05)$ sehingga variabel sistem pengendalian intern berpengaruh terhadap kualitas laporan keuangan daerah. Penelitian ini sesuai dengan penelitian Moha, dkk (2017) yang menyatakan bahwa sistem pengendalian intern berpengaruh terhadap kualitas laporan keuangan daerah.

\section{Pengaruh Prinsip Pengelolaan Keuangan Daerah terhadap Kualitas Laporan Keuangan Daerah}


Berdasarkan tabel 4.8 diketahui nilai koefisien regresi dari variabel prinsip pengelolaan keuangan daerah sebesar 0,428 mempunya t hitung sebesar 3,724 dengan probabilitas (sig.) 0,000. Nilai probabilitas (sig) ini lebih kecil dari nilai $\alpha(0,000<0,05)$ sehingga variabel prinsip pengelolaan keuangan daerah berpengaruh terhadap kualitas laporan keuangan daerah. Penelitian ini sesuai dengan penelitian Moha dkk (2017) yang menyatakan bahwa prinsip pengelolaan keuangan daerah berpengaruh terhadap kualitas laporan keuangan daerah.

\section{Pengaruh Penerapan Standar Akuntansi Pemerintahan terhadap Kualitas Laporan Keuangan Daerah}

Berdasarkan tabel 4.8 diketahui nilai koefisien regresi dari variabel penerapan standar akuntansi pemerintahan sebesar 0,056 mempunyai t hitung sebesar 0,417 dengan probabilitas (sig.) 0,67 . Nilai probabilitas (sig.) ini lebih besar dari nilai $\alpha(0,678>0,05)$ sehingga variabel penerapan standar akuntansi pemerintahan tidak berpengaruh terhadap kualitas laporan keuangan daerah. Penelitian ini berbeda dengan penelitian Wati dkk (2014) yang menyatakan bahwa penerapan standar akuntani pemerintahan berpengaruh terhadap kualitas laporan keuangan daerah.

\section{KESIMPULAN}

Hasil dan penelitian ini menunjukkan bahawa secara simultan sistem pengendalia intern, prinsip pengelolaan keuangan daerah, dan penerapan standar akuntansi pemerintahan, berpengaruh terhadap kualitas laporan keuangan daerah. Secara parsial sistem pengendalian intern dan prinsip pengelolaan keuangan daerah berpengaruh terhadap kualitas laporan keuangan daerah. Sedangkan penerapan standar akuntansi pemerintahan tidak berpengaruh terhadap kualitas laporan keuangan daerah.

\section{Saran}

Penelitian selanjutnya dapat mengganti beberapa variabel independen yang dapat mempengaruhi kualitas laporan keuangan agar mendapatkan faktor-faktor yang sebenarnya seperti menambahkan variabel kompetensi sumber daya manusia (Wati dkk, 2015 dan Ariesta, 2013), karena kompetensi sumber daya manusia ditunjukkan agar penyelenggaraan tugas dan fungsi organisasi dalam rangka menghasilkan laporan keuangan daerah yang berkualitas dapat diterapkan. Bisa juga menambahkan variabel pemanfaatan teknologi dan informasi karena sebagian besar pembuatan laporan keuangan 
daerah menggunakan teknologi dan informasi. Teknologi dan informasi berperan dalam menyediakan informasi yang bermanfaat bagi para pengambil keputusan di dalam organisasi termasuk dalam hal pelaporan sehingga mendukung proses pengambilan keputusan dengan lebih efektif. Selain itu pada penelitian berikutnya dapat menambah metode wawancara agar jawaban dari responden dan hasil yang didapat lebih valid.

\section{DAFTAR PUSTAKA}

Bastian, Indra. 2009. Akuntansi Sektor Publik di Indonesia. Yogyakarta: BPFE-Yogyalarta

Bastian, Indra. 2010. Akuntansi Sektor Publik Suatu Pengantar. Edisi Ketiga. Yogyakarta: Erlangga

Bungin, Burhan. 2014. Metode Penelitian Kuantitatif. Edisi Kedua. Jakarta: Kencana

Dewi, Ni Made Rika Krisna; Ni Kadek Sinarwati dan Nyoman Ari Surya Darmawan. 2014. Pengaruh Pemahaman Sistem Akuntansi Keuangan Daerah dan Pengelolaan Keuangan Daerah terhadap Kualitas Laporan Keungan Pemerintah Daerah (Studi Empiris pada 10 SKPD Berupa Dinas di Kabupaten Jembrana). Vol. 2 No. 1

Evicahyani, Sagung Inten dan Nyoman Djinar Setiawina. 2016. Analisis Faktor-faktor yang Mempengaruhi Kualitas Laporan Keuangan Pemerintah daerah Kabupaten Tabanan. ISSN 2337-3067 Vol 5 No. 3

Faishol, Ahmad. 2016. Pengaruh Sistem Pengendalian Intern terhadap Kualitas Laporan Keuangan (Studi Kasus pada Satuan Kerja Perangkat Daerah Pemerintah Kabupaten Lamongan). ISSN 2504-3764 Vol. 1 No. 3

Ghozali, Imam. 2013. Aplikasi Analisis Multivariete dengan Program IMB SPSS 23. Edsi 8. Semarang: Badan Penerbit UNDIP

Gilardi, Fabrizio. 2001. Prinsipal-Agent Models Go to Europe Independent Regulatory Agencies as Ultimate Step of Delegation Paper Presemtend at the ECPR General Conterence Canterbury (UK). 6-8 September 2001

Halim, Abdul dan Muhammad Syam. 2012. Akuntansi Sektor Publik. Jakarat: Selemba Empat

Hart. 2017. Berita Seputar Perwakilan BPKP Provinsi Jawa Tengah, Jepara Raih Opini WTP. Diakses 10 Januari 2018 www.bpkp.go.id/jateng/berita/read/6498/160/Jepara-Raih-OpiniWTP.bpkp

Hasibuan, Wildan Ansory. 2015. Peranan Sistem Pengelolaan Keuangan Pemerintah daerah dan Penerapan Sistem Akuntansi Keuangan Pemeritah Daerah dalam Meningkatkan Kualitas Laporan Kuangan Pemerintah daerah di Kabupaten Padang Lawas Utara, Kabupaten Padang Lawas, Kabupaten Tapanuli Selatan, dan Kota Padangsidimpuan. Skripsi yang dipublikasikan. Universitas Sumatra Utara

Jensen, Michael C. dan William H. Meckling. 1976. Theory of the Firm: Managerial Behavior, Agency Costs and Ownership Structure. Journal of Financial Economics. Vol. 3 No. 4

Indriantoro, Nur dan Bambang Supomo. 2011. Metodologi Penelitian Bisnis untuk Akuntansi dan Manajemen. Yogyakarta: BPFE-Yogyakarta

Keputusan Mentri dalam Negeri Nomor 29 Tahun 2002 Tentang Pedoman Pengurusan, Pertanggungjawaban, dan Pengawasan Keuangan Daerah serta Tata Cara Penyusunan Anggaran Pendapatan dan Belanja Daerah, Pelaksanaan Tata Usaha Keuangan Daerah dan Penyusunan Perhitungan Anggaran Penapatan dan Belanja Daerah

Kuncoro, Mudrajad. 2003. Metode Riset untuk Bisnis dan Ekonomi. Jakarta: Erlangga

Kurniawan, Ferdy. Laporan Keuangan Pemkab Jepara Perolehan Opini WTP. Diakses 10 Januari 2018

https://rlisafmjepara.com/2013/06/laporan-keuangan-pemkab-jepara-peroleh-opini-wtp/

Lubis, Arfan Ikhsan dan Muhammad Ishak. 2005. Akuntansi Keperilakuan. Jakarta: Selemba Empat 
Mahmudi. 2010. Manajemen Keuangan Daerah. Jakarta: Erlangga

Moha, Febriyani; Lintje Kalangi dan Jessy D.L. Warongan. 2017. Pengaruh Sistem Pengendalian Intern dan Prinsip Pengelolaan Keuangan Daerah terhadap Kualitas Laporan Keuangan pada Pemerintah daerah Kabupaten Bolaang Mongondow Selatan. Vol. 5 No. 2

Mursyidi. 2009. Akuntansi Pemerintah di Indonesia. Bandung: PT. Refika Aditama

Nagor, Teuku Fahtian; Darwanis dan Abdullah Syukriy. 2015. Pengaruh Penerapan Sistem Pengendalian Intern dan Penerapan Prinsip Pengelolaan Keuangan Daerah terhadap Kualitas Laporan Keuangan Pemerintah Daerah Kabupaten Aceh Barat. ISSN 2302-0164 Vol. 4 No. 1

Novita, Kiki; Yunus Tete Konde dan Anisa Kusumawardani. 2017. Pengaruh Sistem Penendalian Intern dan Penerapan Prinsip Pengelolaan Keuangan Daerah terhadap Kualitas Laporan Keuangan Daerah pada Pemerintah Kota Samarinda. Vol. 2 No. 2.

Oktarina, Mia; Kharis Raharjo dan Rita Andini. 2016. Pengaruh Penerapan Strandar Akuntansi Pemerintahan, Kualitas Aparatur Pemerintah daerah, dan Good Governance terhadap Kualitas Laporan Keuangan di Kota Semarang. Vol. 2 No. 2,

Patra, A. Dahri Adi; Lanteng Bustami dan Hasriani. 2015. Pengaruh Penerapan Sistem Akuntansi Keuanga Pemerintah daerah terhadap Kualitas Laporan Keuangan Pemerintah daerah. Vol. 02 No. 01

Peraturan Mentri Dalam Negeri Nomor 13 Tahun 2006 tentang Pedoman Pengelolaan Keuangan Daerah

Peraturan Mentri Dalam Negeri Nomor 64 Tahun 2013 tentang Standar Akuntansi Pemerintahan

Peraturan Pemerintah Nomor 58 Tahun 2005 tentang Pengelolaan Keuangan Daerah

Peraturan Pemerintah Nomor 60 Tahun 2008 tentang Sistem Pengendalian Intern Pemerintah

Peraturan Pemerintah Nomor 71 Tahun 2010 tentang Standar Akuntansi Pemerintahan.

Susilowati, Indah. 1998. Fisheries Regulation and Eforcement in Indonesia, Malaysia, and the Philippines. Journal of Costail Development Vol 2 No 1

Wati, Kadek Desiana; Nyoman Trisna Herawati dan Ni Kadek Sinarwati. 2014. Pengaruh Kompetensi SDM, Penerapan SAP, dan Sistem Akuntansi Keuangan Daerah terhadap Kualitas Laporan Keuangan Daerah. Vol. 02 No. 1, Tahun 2014 